Research article

\title{
Mechanisms underlying the growth inhibitory effects of the cyclo-oxygenase-2 inhibitor celecoxib in human breast cancer cells
}

\author{
Gargi D Basu, Latha B Pathangey, Teresa L Tinder, Sandra J Gendler and Pinku Mukherjee
}

Department of Biochemistry and Molecular Biology, Mayo Clinic College of Medicine, Scottsdale, Arizona, USA

Corresponding author: Pinku Mukherjee, mukherjee.pinku@mayo.edu

Received: 1 Oct 2004 Revisions requested: 14 Dec 2004 Revisions received: 1 Mar 2005 Accepted: 4 Mar 2005 Published: 4 Apr 2005

Breast Cancer Research 2005, 7:R422-R435 (DOI 10.1186/bcr1019)

This article is online at: http://breast-cancer-research.com/content/7/4/R422

(c) 2005 Basu et al.; licensee BioMed Central Ltd.

This is an Open Access article distributed under the terms of the Creative Commons Attribution License (http://creativecommons.org/licenses/by/

2.0), which permits unrestricted use, distribution, and reproduction in any medium, provided the original work is properly cited.

\begin{abstract}
Introduction Inhibitors of cyclo-oxygenase (COX)-2 are being extensively studied as anticancer agents. In the present study we evaluated the mechanisms by which a highly selective COX2 inhibitor, celecoxib, affects tumor growth of two differentially invasive human breast cancer cell lines.
\end{abstract}

Methods MDA-MB-231 (highly invasive) and MDA-MB-468 (moderately invasive) cell lines were treated with varying concentrations of celecoxib in vitro, and the effects of this agent on cell growth and angiogenesis were monitored by evaluating cell proliferation, apoptosis, cell cycle arrest, and vasculogenic mimicry. The in vitro results of MDA-MB-231 cell line were further confirmed in vivo in a mouse xenograft model.

Results The highly invasive MDA-MB-231 cells express higher levels of COX-2 than do the less invasive MDA-MB-468 cells. Celecoxib treatment inhibited COX-2 activity, indicated by prostaglandin $\mathrm{E}_{2}$ secretion, and caused significant growth arrest in both breast cancer cell lines. In the highly invasive MDA-MB231 cells, the mechanism of celecoxib-induced growth arrest was by induction of apoptosis, associated with reduced activation of protein kinase B/Akt, and subsequent activation of caspases 3 and 7 . In the less invasive MDA-MB-468 cells, growth arrest was a consequence of cell cycle arrest at the $G_{0} /$ $\mathrm{G}_{1}$ checkpoint. Celecoxib-induced growth inhibition was reversed by addition of exogenous prostaglandin $E_{2}$ in MDAMB-468 cells but not in MDA-MB-231 cells. Furthermore, MDAMB-468 cells formed significantly fewer extracellular matrix associated microvascular channels in vitro than did the high COX-2 expressing MDA-MB-231 cells. Celecoxib treatment not only inhibited cell growth and vascular channel formation but also reduced vascular endothelial growth factor levels. The in vitro findings corroborated in vivo data from a mouse xenograft model in which daily administration of celecoxib significantly reduced tumor growth of MDA-MB-231 cells, which was associated with reduced vascularization and increased necrosis in the tumor mass.

Conclusion The disparate molecular mechanisms of celecoxibinduced growth inhibition in human breast cancer cells depends upon the level of COX-2 expression and the invasive potential of the cell lines examined. Data suggest a role for COX-2 not only in the growth of cancer cells but also in activating the angiogenic pathway through regulating levels of vascular endothelial growth factor.

\section{Introduction}

The incidence of breast cancer - the second leading cause of cancer death in women in the USA - is increasing, and current therapy is unable to achieve clinical responses in patients with highly invasive metastatic disease. There is a consequent need for more effective approaches to prevention and treatment of breast cancer. Nonsteroidal anti-inflammatory drugs (NSAIDs) show great promise in this respect. Recent data on regular NSAID use for 5-9 years indicated a $21 \%$ reduction in the incidence of breast cancer, and regular NSAID use for 10 or more years produced a $28 \%$ reduction in the incidence of breast cancer [1]. Preclinical studies [2-4] have consistently shown that NSAIDs inhibit mammary carcinogenesis.

$\overline{\mathrm{CDK}}=$ cyclin-dependent kinase; $\mathrm{COX}=$ cyclo-oxygenase; DMEM = Dulbecco's modified eagle medium; DMSO = dimethyl sulfoxide; FCS = fetal calf serum; NSAID = nonsteroidal anti-inflammatory drug; pAkt = phosphorylated Akt; PBS = phosphate-buffered saline; $\mathrm{PG}=$ prostaglandin; $\mathrm{PI}=$ propidium iodide; VEGF = vascular endothelial growth factor. 
Various mechanisms may be responsible for the observed effects of NSAIDs against breast cancer. Inhibition of cyclooxygenase (COX), particularly the COX-2 isozyme, and blockade of the prostaglandin (PG) cascade may have impacts on neoplastic growth and development by inhibiting several key features of mammary carcinogenesis - namely proliferation, angiogenesis and metastasis. Inhibition of COX also causes induction of apoptosis in malignant cells and enhances antineoplastic activity of cytotoxic T lymphocytes [5-8]. Our study conducted in newly diagnosed stage I and stage II breast cancer patients [9] showed impaired functionality of $T$ cells and dendritic cells, which correlated with COX-2 overexpression in the tumors and increased levels of $\mathrm{PGE}_{2}$ in the serum and tumor milieu. Therefore, a convincing case has been made for COX-2 being an important target for the antineoplastic action of NSAIDs. Unlike NSAIDs, COX-2 selective inhibitors such as celecoxib and rofecoxib do not inhibit COX-1 and thus show promise as drugs that spare the gastrointestinal system.

COX-2 is overexpressed in breast cancer tissues, and greater extent of its expression is associated with poorer prognosis [10]. Various environmental and nutritional risk factors induce COX-2 expression in animal models of breast cancer $[11,12]$. Moreover, COX-2 selective inhibitors significantly delayed the incidence of mammary tumors in transgenic mice expressing the Her2/Neu, and polyoma-middle $\mathrm{T}$ oncogenes [13,14]. Recently, a transgenic mouse model was developed in which the human COX-2 gene was expressed in the mammary gland under the control of the murine mammary tumor virus promoter [15]. That study demonstrated that enhanced COX-2 expression strongly predisposes to transformation of the mammary gland in multiparous animals. These data strongly suggest that local expression of COX-2 is sufficient for in situ tumor initiation and/or progression. Another transgenic overexpression study with COX-2 targeted to the epidermis also supports the concept that COX-2 is a critical regulator of tumor progression [16]. Transfections of the breast cancer cell line Hs578T with cDNA for COX-2 led to an increase in expression and activity of matrix metalloproteinase-2, resulting in increasingly invasive behavior of the cells [17]. COX-2 specific inhibitors have the ability to block cell growth, and induce apoptosis and cell cycle arrest in murine mammary tumor cell lines [18]. However, the molecular mechanisms involved are not well understood. If COX-2 inhibitors act only by modulating COX-2 expression, then that would imply that this therapy would be limited to COX-2 overexpressing tumors; hence, this question is of considerable clinical importance.

In the present study we established that the level of COX-2 expression and the invasive property of breast cancer cells determines the mechanism of celecoxib-induced growth inhibition; that COX-2 is involved in extracellular matrix associated microvascular channel formation by breast cancer cells; and that COX-2 inhibits angiogenesis in vivo. The study should further our understanding of the cellular and molecular mecha- nisms underlying the chemopreventive effect of a COX-2 selective inhibitor in breast cancer. To the best of our knowledge, this is the first study demonstrating the diverse mode of action of celecoxib on human breast cancer cells, which may be dependent upon the cells' invasive properties and levels of COX-2 expression. This is also the first report suggesting a direct role for COX-2 in matrix associated microvascular channel formation by breast cancer cells.

\section{Methods \\ Cell culture}

The human breast cancer cell lines MDA-MB-231 and MDAMB-468 were obtained from the American Type Culture Collection (ATCC; Rockville, MD, USA) and cultured following instructions from the ATCC. Briefly, cells were grown in Dulbecco's modified eagle medium (DMEM; GIBCO-BRL, Rockville, MD, USA) supplemented with $5 \%$ fetal calf serum (FCS), $100 \mathrm{U}$ penicillin, $0.1 \mu \mathrm{g}$ streptomycin and $2 \mathrm{mmol} / \mathrm{L} \mathrm{L}$-glutamax. Cells were maintained in log phase in $37^{\circ} \mathrm{C}$ incubator with $10 \%$ carbon dioxide. For each experiment cells were plated in FCS-containing media in $58 \mathrm{~cm}^{2}$ culture dishes at a cell density of approximately $1 \times 10^{6} \mathrm{cells} / \mathrm{dish}$ and incubated for another 48 hours. Cell cultures were treated with increasing concentrations of celecoxib (20-60 $\mu \mathrm{mol} / \mathrm{l}$; Pfizer, New York, NY, USA) and with dimethyl sulfoxide (DMSO; the vehicle in which celecoxib was dissolved). The concentration of celecoxib used in our experiments is clinically relevant because the serum concentrations of COX-2 inhibitors in patients range from 20 to $100 \mu \mathrm{mol} / /$ [19]. The concentrations used in the study are based on our titrations with celecoxib for the two cell lines and from several published references on other cell lines [20-22]. In both the cell lines tested there was no evidence of apoptosis or cell cycle arrest at concentrations below $20 \mu \mathrm{mol} / \mathrm{l}$.

\section{SDS-PAGE immunoblotting}

Following harvesting of adherent cells by scraping, cell lysates were prepared and quantified by BCA assay. Lysates $(100 \mu \mathrm{g})$ were resolved on a $10-15 \%$ acrylamide gel and electroblotted onto immobilon-P polyvinylidene diflouride membranes (Sigma, St. Louis, MO, USA). These were probed with primary antibodies for COX-2 (p66), BAX (p23), Bcl-2 (p26), and vascular endothelial growth factor (VEGF; p20), all from Santa Cruz Biotechnology Inc. (Santa Cruz, CA, USA), and phosphorylated Akt (pAkt; p60; Cell Signaling, Beverly MA, USA), and then probed with the appropriate secondary antibodies. Bound antibodies were detected using an enhanced chemiluminescence detection kit (SuperSignal West Dura, Pierce, Rockford, IL, USA), and developed on high performance chemiluminescence films (Amersham Pharmacia Biotech, Piscataway, NJ, USA).

\section{Proliferation assay}

Cell proliferation was determined by using $\left[{ }^{3} \mathrm{H}\right]$ thymidine incorporation, in which $1 \mu \mathrm{Ci}$ of [ $\left.{ }^{3} \mathrm{H}\right]$ thymidine was added to 
the drug or vehicle treated cultures 16 hours before harvesting using a Packard Cell Harvester (Packard Biosciences, Shelton, CT, USA). Incorporated thymidine was evaluated using the Topcount micro-scintillation counter (Packard Biosciences). Results were expressed as $\left[{ }^{3} \mathrm{H}\right]$ thymidine uptake. All determinations were performed in triplicate. Proliferation is directly correlated to radioactive counts/min. In order to determine whether added $\mathrm{PGE}_{2}$ could counteract the growth inhibitory effect of celecoxib, we treated cells with celecoxib (40 $\mu \mathrm{mol} / \mathrm{l})$ and $12.5-200 \mathrm{pg} / \mathrm{ml} \mathrm{PGE}_{2}$ and incubated them for 96 hours before determining $\left[{ }^{3} \mathrm{H}\right]$ thymidine incorporation, as mentioned above.

\section{Assay for apoptosis}

Following treatment of cells with celecoxib for 48 hours, apoptosis was determined by staining the cells with annexin $V$ and propidium iodide $(\mathrm{PI})$, in accordance with the manufacturer's instructions for use of the BD Pharmingen (San Diego, CA, USA) apoptosis kit. Briefly, an aliquot of $10^{5}$ cells was incubated with annexin V-fluorescein isothiocyanate and $\mathrm{PI}$ for 15 $\mathrm{min}$ at room temperature in the dark. Cells were immediately analyzed by flow cytometry. Viable cells exclude PI and are negative for annexin $V$ staining, whereas early apoptotic cells are annexin $\mathrm{V}$ positive and $\mathrm{PI}$ negative. Cells that are not viable due to apoptotic cell death stain positive for annexin $\mathrm{V}$ and $\mathrm{PI}$. The percentage of stained cells in each quadrant was quantified using CellQuest software (BD Biosciences, San Jose, CA, USA) and the total number of apoptotic cells (both early and late apoptosis) was quantified.

\section{Confocal microscopy for detection of apoptotic bodies}

Cells were grown with celecoxib $(60 \mu \mathrm{mol} / \mathrm{l})$ for 48 hours and then trypsinized. Cells were resuspended in phosphate-buffered saline (PBS) with $0.1 \%$ bovine serumn albumin at a final concentration of $5 \times 10^{7} \mathrm{cells} / \mathrm{ml}$ and $2 \mu \mathrm{l}$ of $5 \mathrm{mmol} / \mathrm{l}$ carboxyfluoroscein succinimidyl ester (CFSE)/ml (Molecular Probes, Eugene, OR, USA) was added. After 10 min of incubation at $37^{\circ} \mathrm{C}$ the staining was quenched by adding five times the volume of ice-cold PBS and excess stain was washed off by repeated washes in PBS. Cells were fixed in 95\% ethanol for 1 hour on ice and resuspended in PBS containing $20 \mu \mathrm{g} / \mathrm{ml} \mathrm{PI}$ (Sigma) and $15 \mu \mathrm{g} / \mathrm{ml}$ RNase A (Sigma). Images were captured on the LSM510 confocal microscope (Carl Zeiss Inc., Gottingen, Germany) using excitation wavelengths of $488 \mathrm{~nm}$ (for CFSE) and $543 \mathrm{~nm}$ (for PI).

\section{Assay for caspases 3 and 7}

To evaluate whether celecoxib treatment can induce activation of caspases 3 and 7, we detected levels of active forms of caspases 3 and 7 in cell lysates from treated and untreated cells using the EnzChek Caspase-3/7 Assay Kit (Molecular Probes), in accordance with the manufacturer's protocol. In principle, active caspase 3 or 7 cleaves a fluorogenic substrate; this releases the fluorochrome, which is detected using a spectrofluorometer.

\section{Cell cycle analysis}

Cells were treated with increasing concentrations (20-60 $\mu \mathrm{mol} / \mathrm{l})$ of celecoxib or DMSO (vehicle) in medium supplemented with 5\% FCS for 48 hours. The adherent and the nonadherent cell fractions were harvested and cell pellets were fixed and permeabilized in 95\% cold ethanol, and resuspended in PBS containing $20 \mu \mathrm{g} / \mathrm{ml} \mathrm{PI} \mathrm{(Sigma)} \mathrm{and} 15 \mu \mathrm{g} / \mathrm{ml}$ RNase A (Sigma). Samples were incubated in the dark at $37^{\circ} \mathrm{C}$ for $30 \mathrm{~min}$ and analyzed by flow cytometry (Becton Dickinson, San Diego, CA, USA). For each sample, 50,000 fluorescent cells were counted. Data were analyzed using the ModFit software (Verity Software House Inc., Topsham, ME, USA) to determine DNA content and cell cycle phase $\left(G_{0} / G_{1}-S-G_{2} /\right.$ $M$ phase). Cell doublets and clumps were eliminated from the analyses by gating.

\section{Prostaglandin $\mathrm{E}_{2}$ production}

Cells were treated with increasing concentrations (20-60 $\mu \mathrm{mol} / \mathrm{l}$ ) celecoxib or DMSO (vehicle) in medium supplemented with $5 \%$ FCS for 48 hours. Levels of $\mathrm{PGE}_{2}$ released in media were measured using a $P G E_{2}$ enzyme immunoassay kit from Cayman Chemical Co. (Ann Arbor, MI, USA). Medium was sampled, centrifuged to remove floating cells and frozen immediately at $-70^{\circ} \mathrm{C}$ until assay. The $\mathrm{PGE}_{2}$ assay was performed in accordance with the manufacturer's instructions, following dilution to ensure that readings were within the limits of accurate detection by the assay. The results are expressed as $\mathrm{pg}$ $\mathrm{PGE}_{2} / \mathrm{ml} \pm$ standard deviation.

\section{Assay for vasculogenic mimicry}

This assay was performed as described [23]. Cells were grown until they were about $80 \%$ confluent. The growth medium was replaced with serum-free DMEM supplemented with $100 \mu \mathrm{g} / \mathrm{ml}$ heparin (Elkins-Sinn, Inc. Cherry Hill, NJ, USA) and antibiotics, and cells were incubated for 24 additional hours. The cells were trypsinized, counted, and resuspended in media (at a concentration of $4 \times 10^{4} \mathrm{cells} / \mathrm{ml}$ ) containing 40 and $60 \mu \mathrm{mol} / / \mathrm{l}$ concentrations of celecoxib or vehicle. The wells of a 24-well tissue culture plate were evenly coated with $0.1 \mathrm{ml} /$ well growth factor reduced Matrigel (BD Biosciences), which was allowed to solidify at $37^{\circ} \mathrm{C}$ for $30 \mathrm{~min}$, in accordance with the manufacturer's instructions, before the cells were plated. The cell suspension was plated $(1 \mathrm{ml} /$ well) onto the surface of Matrigel and incubated at $37^{\circ} \mathrm{C}$ for 48 hours and photographed using a Nikon inverted phase contrast photomicroscope (Nikon USA, Garden City, NY, USA). Channel formation was quantified as percentage of channels formed by counting the number of connected cells in five randomly selected fields, using $200 \times$ magnification, and dividing the number by the total number of cells in the same field.

\section{Xenografts}

Male athymic nude mice (age 6-8 weeks) were obtained from NxGen Biosciences Inc. (San Diego, CA, USA) and animals were housed under specific pathogen-free conditions. Five 
mice/group were prophylactically treated with either celecoxib (25 mg/kg body weight) or vehicle DMSO for 7 days before the tumor cells were inoculated. MDA-MB-231 cells were harvested by centrifugation and $5 \times 10^{6}$ cells were suspended in $150 \mu \mathrm{l}$ of serum free DMEM with an equal volume of cold liquid Matrigel $(10 \mathrm{mg} / \mathrm{ml})$. The suspension was injected subcutaneously in the mice. In order to determine the optimal cell number to be injected, titration with varying cell numbers was done on nude mice and the tumorigenicity of the cell line determined. The growth of these tumors was monitored by weekly examination, and growth rates were determined using caliper measurements. Tumor weight was calculated according to the following equation [24]: tumor weight $(\mathrm{g})=($ length $(\mathrm{cm}) \times$ width $\left.(\mathrm{cm})^{2}\right) \times 0.5$. Experiments were terminated 45 days after tumor cell injection. It was necessary to kill some of the mice earlier because of the aggressive nature of the tumor.

\section{Histologic studies}

All solid tumors resulting were excised and fixed in formaldehyde, and paraffin-embedded blocks was sectioned at a thickness of $7 \mu \mathrm{m}$. Histologic evaluation of vascularity was determined by Masson's trichrome staining [25]. This method stains fibrous tissue and stroma green. Blood vessels containing red blood cells stain bright red. Immunohistochemical localization of factor VIII related antigen on endothelial cells was determined using the polyclonal rabbit antihuman von Willebrand factor purchased from Dako Cytomation (Glostrup, Denmark), using the manufacturer's recommended staining protocol.

\section{Statistical analysis}

The celecoxib experiments were run in triplicate; the mean as well as standard deviations were computed. The means were then compared using one-way analysis of variance with Dunnett adjustment.

\section{Results \\ Cyclo-oxygenase-2 protein is differentially expressed in breast cancer cell lines}

We studied two human breast cancer cell lines, MDA-MB-231 and MDA-MB-468, for COX-2 expression by western blotting. Both cell lines expressed COX-2, although MDA-MB-468 cells exhibited lower protein expression than did MDA-MB231 cells. Western blot analysis for COX-2 protein in the MDA-MB-231 cell line showed little change in protein expression after treatment with $20-40 \mu \mathrm{mol} / \mathrm{l}$ celecoxib. At the level of $60 \mu \mathrm{mol} / \mathrm{l}$ there was a slight increase in COX-2 expression. However, in the MDA-MB-468 cell line there was significant downregulation of COX-2 expression upon drug treatment (Fig. 1a).

\section{Celecoxib inhibits growth and proliferation of breast cancer cell lines}

Celecoxib at concentrations of 20,40 , and $60 \mu \mathrm{mol} / \mathrm{l}$ was used to treat the two cell lines for 48 hours. Under the phase contrast microscope, both cell lines exhibited a dramatic morphologic change as well as growth arrest after 48 hours of drug treatment (data not shown). The rate of proliferation in response to celecoxib treatment was assayed by measuring incorporation of $\left[{ }^{3} \mathrm{H}\right]$ thymidine uptake. Significant inhibition of proliferation was observed in both cell lines in a dose-dependent manner, in response to varying concentrations of celecoxib at 96 hours after treatment $(P<0.001$; Fig. 1b). Similar growth inhibition was observed at earlier time points (48 and 72 hours after treatment (data not shown).

\section{Celecoxib induces apoptosis in MDA-MB-231 but not in MDA-MB-468 cells}

Because COX inhibitors have been reported to mediate apoptosis in many cells $[26,27]$, we investigated whether the observed growth inhibition mediated by celecoxib was associated with induction of programmed cell death. Flow cytometric analysis of annexin V/PI staining in celecoxib-treated and vehicle-treated cells was used to analyze apoptosis. Following 48 hours of drug treatment, induction of apoptosis was observed in the MDA-MB-231 cells in a dose-dependent manner (Fig. 2a). Celecoxib at concentrations of 40 and $60 \mu \mathrm{mol} / \mathrm{l}$ caused significant increases in the percentage apoptotic cells $(P=$ 0.01 and $P<0.001$, respectively). In the MDA-MB-468 cell line apoptosis was not induced with celecoxib treatment (Fig. 2a). In spite of the lack of evidence of increased apoptosis, MDA-MB-468 cells had significantly lower proliferation after drug treatment (Fig. 1b). Treated cells appeared rounded up and exhibited atypical morphology (data not shown), which suggested that alterations in the adhesive properties of these cells might have occurred and other pathways may be involved in the growth inhibition observed in MDA-MB-468 cells.

\section{Celecoxib induces formation of apoptotic bodies and loss of nuclear envelope integrity in MDA-MB-231 cells}

To follow up on the celecoxib-induced apoptosis of the MDAMB-231 cells, we analyzed morphological changes in MDAMB-231 cells after celecoxib treatment using confocal microscopy. Celecoxib at concentrations of 40 and $60 \mu \mathrm{mol} / \mathrm{I}$ caused loss of integrity of nuclear envelope and induced formation of peripheral, sharply delineated masses of condensed chromatin or apoptotic bodies, which are characteristic structural features of apoptosis (Fig. 2b-e). Membrane blebbing was also observed, along with loss of plasma membrane integrity in some cells (data not shown). These results indicate that celecoxib treatment caused architectural changes in membrane and cell nucleus within 48 hours of treatment. No such changes were observed in MDA-MB-468 cells (data not shown), which correlated with our observation that there was no significant induction of apoptosis in these cells after celecoxib treatment (Fig. 2a). 


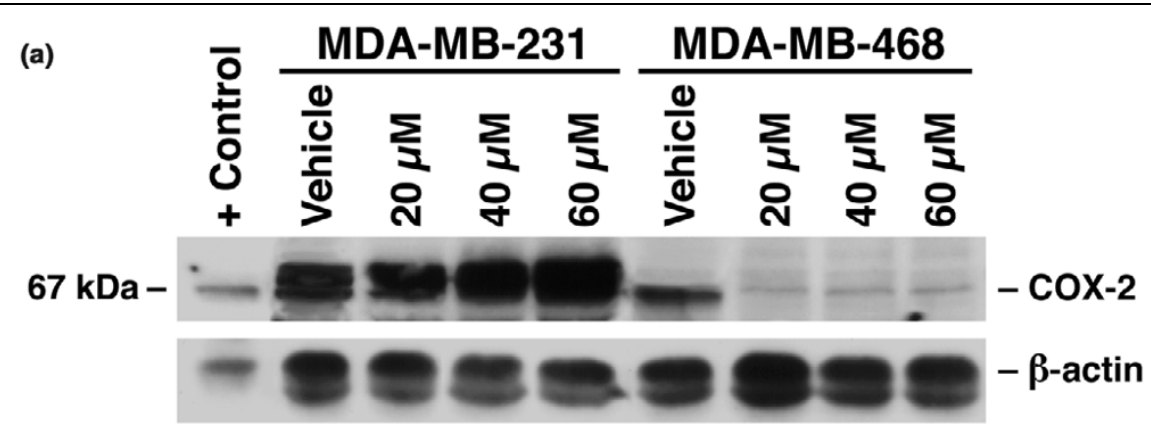

(b)

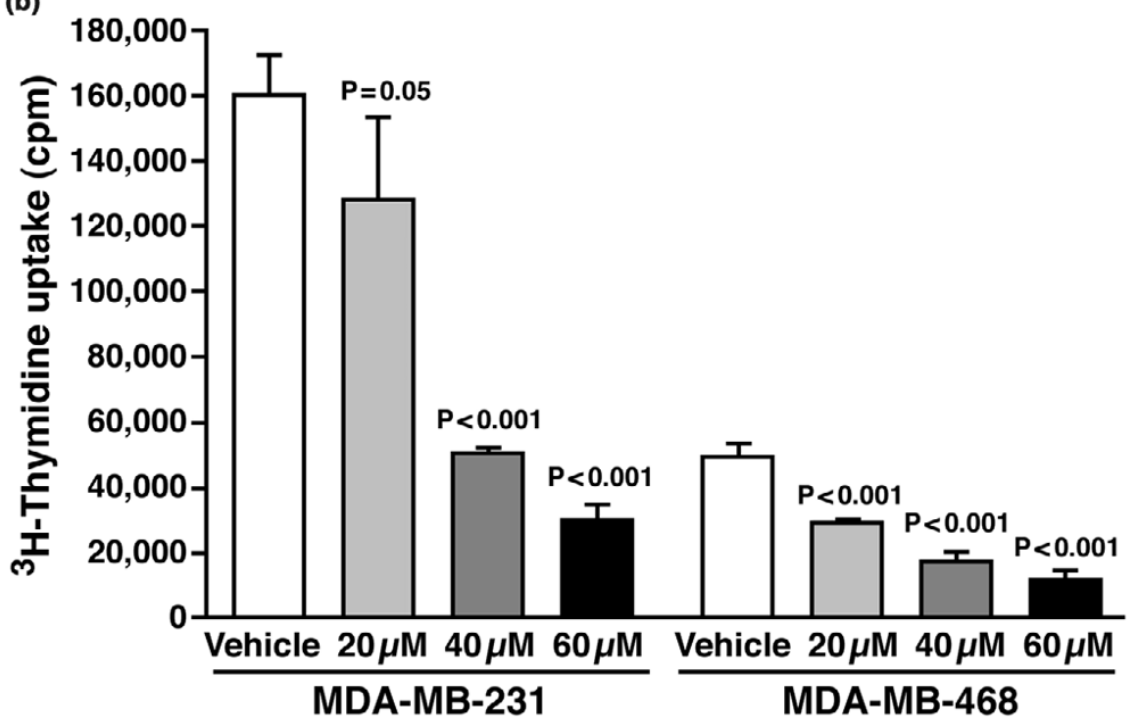

Celecoxib regulates COX-2 levels and causes growth arrest in human breast cancer cells. (a) Cyclo-oxygenase (COX)-2 is expressed in both MDAMB-231 and MDA-MB-468 cell lines. Western blot analysis of vehicle and celecoxib (20-60 $\mu \mathrm{mol} / \mathrm{l})$ treated cells. SDS-PAGE electrophoresis was performed using a 10\% resolving gel. Protein was loaded at $100 \mu \mathrm{g}$ per lane. Lipopolysaccharide/phorbol 12-myristate 13-acetate treated whole cell lysate from RAW264.7 cell line was used as positive control. Gels were blotted and probed with COX-2 monoclonal antibody. Both cell lines expressed COX-2. MDA-MB-231 cells expressed higher levels of COX-2 than did MDA-MB-468 cells. With drug treatment, COX-2 protein level did not change in the MDA-MB-231 cells, but there was reduction in the level of COX-2 protein in the MDA-MB-468 cells after treatment. $\beta$-Actin blot is included to confirm equal loading. These experiments were repeated three times with similar results. (b) Celecoxib induced dose-dependent inhibition of proliferation of breast cancer cell lines. Cells were incubated for 4 days with vehicle or celecoxib, and $\left[{ }^{3} \mathrm{H}\right]$ thymidine was added 24 hours before harvest. After washing off excess thymidine, cells were lysed with 5\% Triton X-100, and incorporated thymidine was evaluated. Celecoxib treatment caused significant dose-dependent growth inhibition in both human breast cancer cell lines. Mean values of three experiments \pm standard deviation is shown. $P$ values represent significant differences between vehicle control and celecoxib treatment.

\section{Celecoxib inhibits activation of protein kinase B/Akt kinase in MDA-MB-231 cells}

Protein kinase $B, A k t$, is a serine/threonine protein kinase that is involved in promoting cell survival signals through the phosphoinositide 3-kinase pathway, leading to inactivation of a series of proapoptotic proteins. Akt also represents a key signaling component in cell survival by mediating the activation of downstream effectors such as BAD $[28,29]$ and procaspase9 [30]. Celecoxib was recently shown to induce apoptosis of cancer cells by blocking Akt activation in rat cholangiocarcinoma and human prostate cancer cells in vitro $[21,22]$. To explore whether inhibition of Akt activation may be the mechanism responsible for induction of apoptosis in MDA-MB-231 cells, we determined the effect of celecoxib on phosphoryla- tion of Akt on breast cancer cell lines. Breast cancer cells were exposed to varying doses of celecoxib for 48 hours, and Akt and pAkt in cell lysates were determined by western blot analysis. At a concentration of $20 \mu \mathrm{mol} / \mathrm{l}$, celecoxib caused slight increase in pAkt in MDA-MB-231 cells. At a concentration of $60 \mu \mathrm{mol} / \mathrm{l}$, celecoxib treatment significantly $(P=0.002)$ downregulated the level of phosphorylation of Akt in MDA-MB-231 cells but not in MDA-MB-468 cells (Fig. 3a,b), suggesting that the mechanism of apoptosis induction in MDA-MB-231 cells was, in part, dependent upon decreased phosphorylation of Akt protein. Because Akt represents a key signaling component in cell survival by activating downstream apoptotic proteins [28-31], we evaluated the levels of Bax and Bcl-2 by western blot analysis of lysates derived from both cell lines 


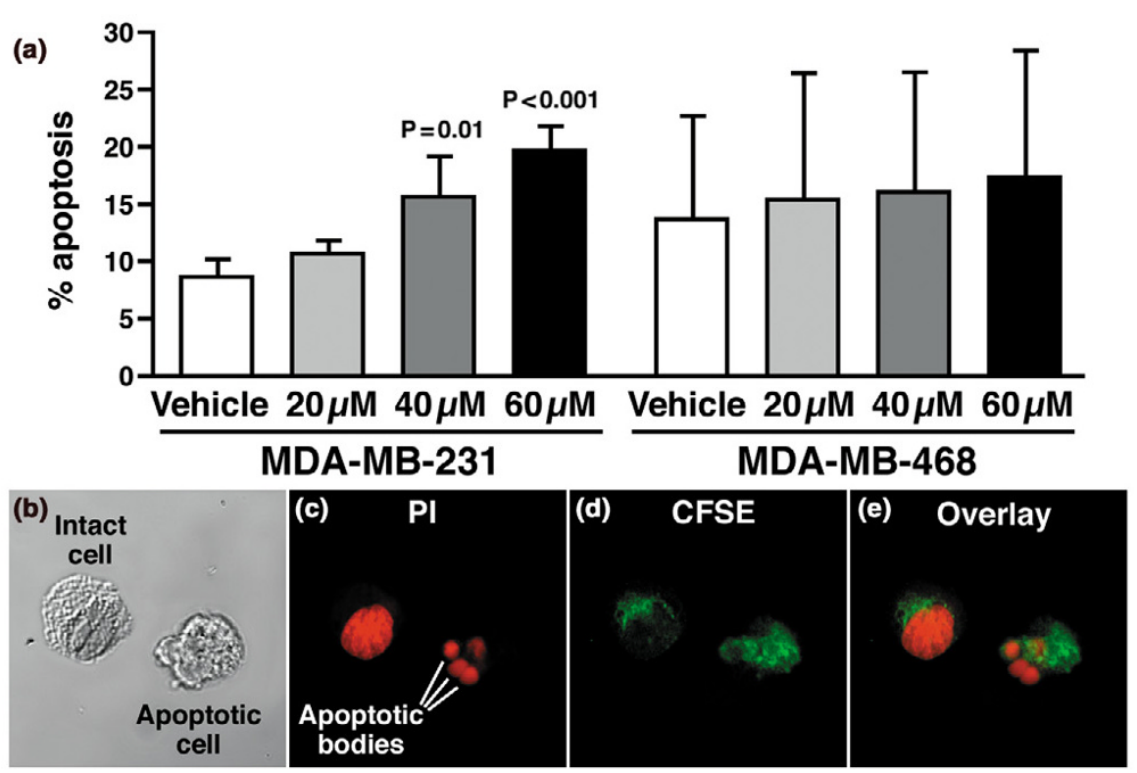

Celecoxib induces apoptosis in MDA-MB-231 cells. (a) Flow cytometric analysis of vehicle-treated and celecoxib-treated cells stained with annexin $\mathrm{V}$ and propidium iodide $(\mathrm{PI})$ was done 48 hours after treatment. The population shown in the figure is total apoptotic cells, which includes early and late apoptosis. Significant induction of apoptosis was observed in the MDA-MB-231 cells at 40 and $60 \mu \mathrm{mol} / \mathrm{l}$ concentrations of celecoxib. Apoptosis was not induced in MDA-MB-468 cells. Mean values of three experiments \pm standard deviation is shown. $P$ values represent significant differences between vehicle control and celecoxib treatment. (b-e) Celecoxib induces formation of apoptotic bodies in MDA-MB-231 cells. Shown are confocal images of MDA-MB-231 cells subjected to 48 hours of celecoxib $(60 \mu \mathrm{mol} / \mathrm{l})$ treatment. Cells were stained with CFSE (panel d) and then fixed in $95 \%$ ethanol and stained with PI (panel c). Cells were visualized in a confocal microscope (Carl Zeiss Inc.) using excitation wavelengths of $488 \mathrm{~nm}$ (for CFSE) and $543 \mathrm{~nm}$ (for PI). Loss of integrity of nuclear envelope and formation of peripheral, sharply delineated masses of condensed chromatin or apoptotic bodies are visualized. Panel b represents phase contrast images of the cells and panel e represents colocalization of CFSE and PI. Images were taken 200x.

after celecoxib treatment. Treatment with celecoxib at concentrations of 40 and $60 \mu \mathrm{mol} / \mathrm{l}$ induced increased expression of Bax in the MDA-MB-231 cells (Fig. 3c), but no significant decrease in Bcl-2 was observed (data not shown). In MDAMB-468 cells, in which apoptosis was not evident, levels of pAkt and Bax remained unchanged with treatment (Fig. 3a,b).

\section{Celecoxib induces caspase-3/7 activation in MDA-MB- 231 cells}

Caspases are responsible for many of the biochemical and morphological changes that occur during apoptosis. Most apoptotic signals induce intracellular cleavage of caspases 3 and 7 from an inactive precursor (p32-p35) to the active forms ( $p 17$ and $p 12)$; hence, these proteins are the most extensively studied apoptotic proteins. The effector caspases 3 and 7 proteolytically cleave and activate several other caspases as well as several other apoptotic proteins, including the DNA fragmentation protein poly-ADP-ribose polymerase (PARP), which is one of the primary activators of DNA fragmentation and cell death [32-34].

We investigated whether celecoxib induced the activation of caspase 3 and caspase 7 in MDA-MB-231 cells in which apoptosis was induced. Caspase activity is presented as fluorescence emission, which is directly proportional to activities of caspases 3 and 7. Treatment with celecoxib (40 and 60 $\mu \mathrm{mol} / \mathrm{l})$ for 48 hours caused significant increases in activation of caspases 3 and 7 (fivefold increase at the $40 \mu \mathrm{mol} / \mathrm{l} \mathrm{con}$ centration $[P=0.008]$ and sixfold increase at the $60 \mu \mathrm{mol} / \mathrm{l}$ concentration $[P=0.002]$; Fig. 3d). Caspase activation was completely blocked by incubation with the caspase inhibitor Ac-DEVD-CHO (data not shown). These results suggest that celecoxib-induced apoptosis in MDA-MB-231 cells is due to activation of caspases 3 and 7 , which is corroborated by studies indicating that the blockade or absence of caspase activation is sufficient to inhibit effective apoptosis [35]. In contrast, caspase activation was not observed in celecoxib-treated MDA-MB-468 cells, which correlated with no significant increase in apoptosis with celecoxib treatment (Fig. 2).

\section{Celecoxib induces cell cycle arrest at the $G_{0} / G_{1}$} checkpoint in MDA-MB-468 but not in MDA-MB-231 cells To determine whether celecoxib-induced growth inhibition was due to changes in cell cycle progression, flow cytometric analysis was performed on cells treated with increasing concentrations of celecoxib (20-60 $\mu \mathrm{mol} / \mathrm{l})$ for 48 hours. In MDAMB-468 cells, in which celecoxib did not induce apoptosis, there was induction of cell cycle arrest. At 40 and $60 \mu \mathrm{mol} / \mathrm{l}$ concentrations of celecoxib, significant increases $(P=0.02$ and $P<0.001$, respectively) in the proportion of cells that 
Figure 3

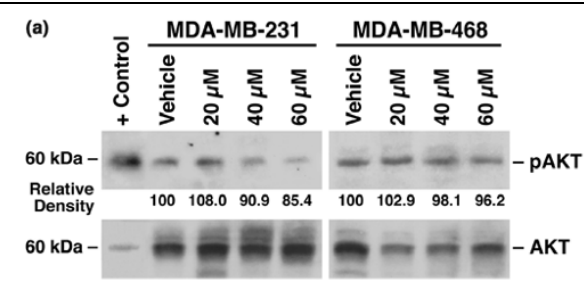

(b)
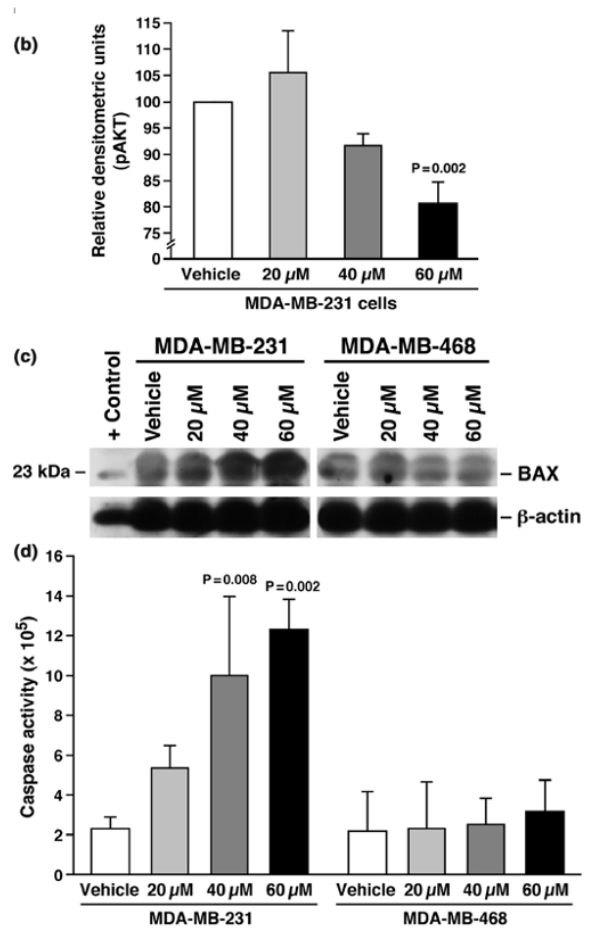

Celecoxib induced down-regulation of pAkt, increase in Bax, and caspase 3/7 in MDA-MB-231 cells. (a) Total Akt and phosphorylated Akt (pAkt). Western blot analysis of cell lysates prepared from vehicle and celecoxib (20-60 $\mu \mathrm{mol} / \mathrm{l})$ treated cells. SDS-PAGE electrophoresis was performed using $10 \%$ resolving gel. Protein was loaded at $100 \mu \mathrm{g}$ per lane and the protein of interest was detected using specific antibodies. Celecoxib treatment at 40 and $60 \mu \mathrm{mol} / \mathrm{l}$ caused decreases in the levels of pAkt in MDA-MB-231 cells, with no change in MDA-MB468 cells. Numbers below each lane represents percentage of protein expression compared with vehicle-treated cell lysate, which was set to equivalent to $100 \%$, as determined by densitometric analysis. Control cell extracts from Jurkats were used as positive control for Akt and pAkt. (b) Average densitometric values of three separate experiments showing reduction in $\mathrm{pAkt}$ with celecoxib treatment. There was a significant decrease $(P=0.002)$ in the levels of pAkt with $60 \mu \mathrm{mol} / \mathrm{l}$ celecoxib treatment. (c) Western blot analysis of BAX. Increased expression of BAX protein was observed with increasing concentrations of celecoxib in MDA-MB-231 cells but not in MDA-MB-468 cells. The experiment was repeated three times with similar results. A $\beta$-actin blot is included to show equal loading. (d) Spectrofluorometric analysis of lysates prepared from vehicle and celecoxib $(20-60 \mu \mathrm{mol} / \mathrm{l})$ treated cells at 48 hours. Activity of caspases 3 and 7 was monitored by enzymatic cleavage using a fluorescence microplate reader with excitation at $485 \pm 10 \mathrm{~nm}$ and emission detection at $530 \pm 12.5 \mathrm{~nm}$. In MDA-MB231 cells, activities of caspases 3 and 7 were increased significantly at $40 \mu \mathrm{mol} / \mathrm{l}$ and $60 \mu \mathrm{mol} / \mathrm{l}$ drug concentrations. No increase in caspase activity was evident in the MDA-MB-468 cells. Mean values from three experiments \pm standard deviation is shown. $P$ values represent significant differences between vehicle control and celecoxib treatment.
Figure 4
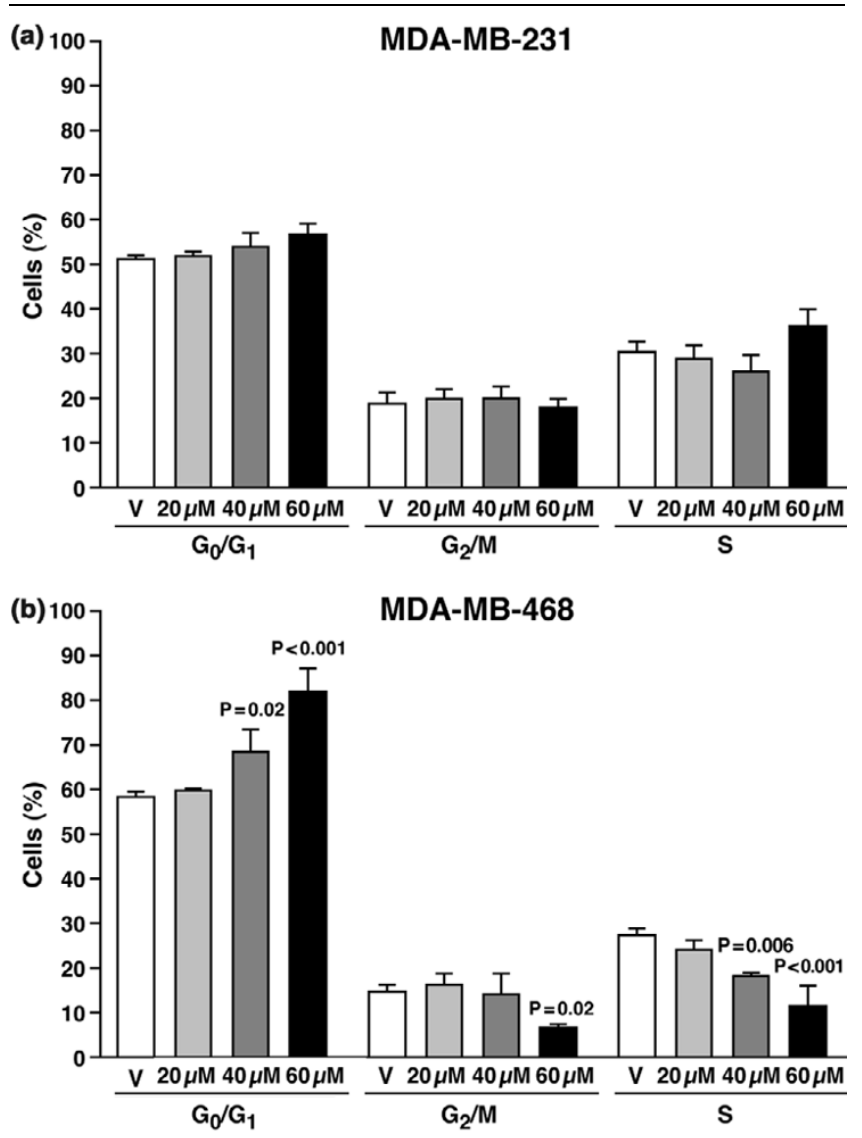

Celecoxib causes cell cycle arrest in MDA-MB-468 cells. (a,b) Flow cytometric analysis of cells subjected to treatment with vehicle or celecoxib $(20-60 \mu \mathrm{mol} / \mathrm{l})$ for 48 hours. Cells were fixed and permeabilized with $95 \%$ ethanol, stained with propidium iodide, and analyzed by flow cytometry. Celecoxib induced growth arrest at the $\mathrm{G}_{0} / \mathrm{G}_{1}$ cell cycle checkpoint in MDA-MB-468 cells (panel b) with no cell cycle arrest in the MDA-MB-231 cells (panel a). Mean values for three experiments \pm standard deviation of the mean is shown. $P$ values represent significant difference between vehicle control and celecoxib treatment. Experiments were repeated three times, with similar results.

were arrested at the $G_{0} / G_{1}$ checkpoint of the cell cycle were observed. Subsequently, significant inhibition of transition to the $\mathrm{G}_{2} / \mathrm{M}$ phase $(P=0.02$ at $60 \mu \mathrm{mol} / \mathrm{l})$ and $S$ phase $(P=$ 0.006 and $P<0.001$ at 40 and $60 \mu \mathrm{mol} / \mathrm{l}$ ) was observed (Fig. 4b). Thus, growth inhibitory activity of celecoxib on these MDA-MB-468 cells was due to cell cycle arrest at $G_{0} / G_{1}$ phase and not due to induction of apoptosis. The cell cycle arrest persisted at 72 hours after drug treatment (data not shown). In MDA-MB-231 cells there was no significant difference in cell cycle progression with celecoxib treatment for 48 hours (Fig. 4a).

\section{Celecoxib inhibits cyclo-oxygenase-2 induced prostaglandin $E_{2}$ production in both cell lines}

COX-2 converts arachidonic acid to bioactive prostanoids. It has been demonstrated that COX-2 derived $P G E_{2}$ is the major 
Table 1

Celecoxib inhibited prostaglandin $E_{2}$ secretion by breast cancer cells

\begin{tabular}{|c|c|c|c|c|}
\hline Treatment & MDA-MB-231 & $P$ value & MDA-MB-468 & $P$ value \\
\hline Vehicle & $430.0 \pm 178.2$ & & $76.6 \pm 15.2$ & \\
\hline Celecoxib $20 \mu \mathrm{mol} / /$ & $30.1 \pm 2.9$ & $<0.01$ & $39.0 \pm 16.5$ & 0.03 \\
\hline Celecoxib $40 \mu \mathrm{mol} / /$ & $30.7 \pm 4.7$ & $<0.01$ & $37.3 \pm 11.0$ & 0.02 \\
\hline Celecoxib $60 \mu \mathrm{mol} / / \mathrm{I}$ & $37.7 \pm 13.6$ & $<0.01$ & $30.3 \pm 13.6$ & 0.01 \\
\hline
\end{tabular}

Forty-eight hours post treatment, conditioned medium from vehicle and celecoxib $(20-60 \mu \mathrm{mol} / \mathrm{l})$ treated cells were harvested and prostaglandin (PG) $E_{2}$ levels $(\mathrm{pg} / \mathrm{ml})$ determined by enzyme-linked immunosorbent assay. In all cell lines, $\mathrm{PGE}_{2}$ levels were significantly reduced at all doses of celecoxib. The experiment was repeated three times and in triplicate. $P$ values represent significant differences between vehicle control and celecoxib treatment.

prostaglandin produced by breast cancer cells [36]. To determine whether COX-2 activity was affected by celecoxib treatment, $\mathrm{PGE}_{2}$ production using a $\mathrm{PGE}_{2}$-specific enzymelinked immunosorbent assay was measured in conditioned medium collected from the breast cancer cell lines after celecoxib-treatment (20-60 $\mu \mathrm{mol} / \mathrm{l})$ for 48 hours. All doses of celecoxib significantly reduced $\mathrm{PGE}_{2}$ secretion by both cell lines $(P<0.01$ for MDA-MB-231 and $P=0.03,0.02$ and 0.01 for MDA-MB-468 cells; Table 1), indicating that celecoxib is a potent inhibitor of COX-2 induced $\mathrm{PGE}_{2}$ production.

\section{Celecoxib-induced growth inhibition is reversed by exogenous prostaglandin $E_{\mathbf{2}}$ only in MDA-MB-468 cells}

Because celecoxib caused growth inhibition in the two breast cancer cell lines and inhibited $\mathrm{PGE}_{2}$ secretion, we hypothesized that this growth inhibition was $\mathrm{PGE}_{2}$ dependent. To determine whether celecoxib-induced growth inhibition could be reversed by exogenous $\mathrm{PGE}_{2}, \mathrm{PGE}_{2}$ was added to cultures of MDA-MB-231 and MDA-MB-468 cells treated with constant dose $(40 \mu \mathrm{mol} / \mathrm{l})$ of celecoxib. Varying amounts of $P \mathrm{PE}_{2}$ $(12.5-200 \mathrm{pg} / \mathrm{ml})$ were added to the medium in order to take into account the fact that some of the $\mathrm{PGE}_{2}$ may degrade or be internalized into cells. In MDA-MB-231 cells, growth inhibition induced by $40 \mu \mathrm{mol} / \mathrm{l}$ celecoxib could not be restored by addition of exogenous $\mathrm{PGE}_{2}$ (Fig. 5a), thereby suggesting that celecoxib-induced growth inhibition in MDA-MB-231 cells may be independent of $\mathrm{PGE}_{2}$ levels. However, addition of 200 $\mathrm{pg} / \mathrm{ml} \mathrm{PGE}{ }_{2}$ completely reversed the growth inhibition induced by $40 \mu \mathrm{mol} / \mathrm{l}$ celecoxib in the less invasive MDA-MB-468 cells (Fig. 5b), suggesting that celecoxib-induced growth regulation of these cell lines may be dependent on the levels of $\mathrm{PGE}_{2}$.

\section{Celecoxib inhibits in vitro matrix-associated vascular channel formation}

Recent findings demonstrate the unusual ability of aggressive human breast cancer cells to form tubular structures in threedimensional Matrigel cultures. The generation of these channels by epithelial tumor cells is called vascular mimicry [3739]. One study [40] suggested a connection between angiogenesis and formation of these channels. Because celecoxib is known to act as an inhibitor of angiogenesis, we investigated the ability of MDA-MB-231 and MDA-MB-468 cells to form the microvascular channels with and without celecoxib treatment. MDA-MB-231 cells, which express elevated levels of COX-2 and are highly invasive, begin to form tubular structures in under 16 hours when plated on Matrigel (data not shown) and form very characterized microvascular channels by 48 hours. In contrast, MDA-MB-468 cells, which have lower COX-2 and are less invasive, start tubule formation much later, at approximately 30 hours, and exhibit significantly fewer microvascular channels at 48 hours than do MDA-MB231 cells. These observations were specific for the high or moderately invasive cells, because the noninvasive breast cancer cells (ZR-75-1) did not form channels in vitro under identical culture conditions (data not shown).

We found that celecoxib treatment at concentrations of 40 and $60 \mu \mathrm{mol} / \mathrm{l}$ was able to reduce significantly the formation of channels in both breast cancer cell lines in a dose-dependent manner, as compared with vehicle treated cells $(P<0.001$ for MDA-MB-231 cells and $P<0.001$ for MDA-MB-468 cells; Fig. 6a), suggesting a role for COX-2 in channel formation. The effect of celecoxib on channel formation was only quantified on live adherent cells in Matrigel as the apoptosed and dead cells float into the media. Thus, we believe that the negative effect of celecoxib on channel formation was not due to cell death, which was also measured by trypan blue exclusion (data not shown).

\section{Celecoxib inhibits expression of vascular endothelial growth factor protein in MDA-MB-231 cells}

Recent reports have shown that a nonspecific COX inhibitor (indomethacin) suppresses the expression of VEGF gene expression in vitro in mammary tumor cells [41]. We evaluated the levels of VEGF protein from tumor lysate of cells treated with vehicle or increasing doses of celecoxib. Compared with control, celecoxib (20-60 $\mu \mathrm{mol} / \mathrm{l})$ treatment reduced expression of VEGF in the MDA-MB-231 cells in a dose-dependent manner (Fig. 6b). No such reduction was observed in the MDA-MB-468 cells treated with celecoxib (Fig. 6b), suggesting that in the highly aggressive MDA-MB-231 cells the COX$2 / \mathrm{PGE}_{2}$ pathway may play a critical role in channel formation 
Figure 5
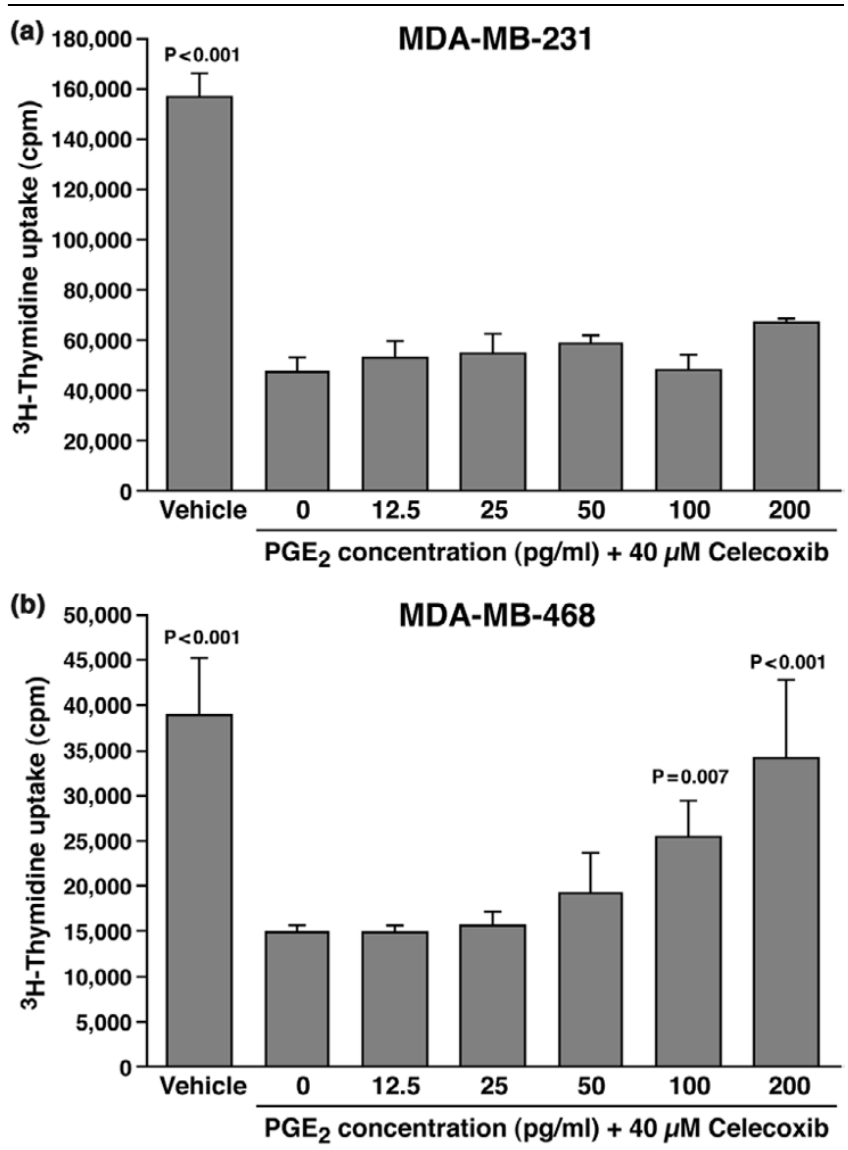

Growth inhibition of MDA-MB-468 cells was abrogated by exogenous prostaglandin $(\mathrm{PG}) \mathrm{E}_{2}$ addition. $\left[{ }^{3} \mathrm{H}\right]$ thymidine uptake assay was done to determine proliferation of (a) MDA-MB-231 and (b) MDA-MB-468 cells treated with $40 \mu \mathrm{mol} / /$ celecoxib with or without varying amounts of exogenous $\mathrm{PGE}_{2}(12.5-200 \mathrm{pg} / \mathrm{ml})$. Cells were harvested after 96 hours in culture. In MDA-MB-231 cells, growth inhibition induced by 40 $\mu \mathrm{mol} / /$ celecoxib could not be restored by addition of exogenous $\mathrm{PGE}_{2}$; however, addition of $200 \mathrm{pg} / \mathrm{ml} \mathrm{PGE}{ }_{2}$ completely reversed the growth inhibition induced by $40 \mu \mathrm{mol} / \mathrm{l}$ celecoxib in the less invasive MDA-MB468 cells. Average values of three experiments \pm standard deviation is shown. $P$ values represent significant differences between vehicle control and celecoxib treatment.

and angiogenesis, in part by activating proangiogenic proteins such as VEGF. Future studies will evaluate other proteins associated with the angiogenic pathway.

\section{In vivo tumor growth was reduced with celecoxib treatment}

Nude mice were prophylactically treated with celecoxib or vehicle for 1 week before tumor challenge with MDA-MB-231 cells in Matrigel. Celecoxib treatment was continued for 45 days after tumor challenge. Mice treated with celecoxib (25 $\mathrm{mg} / \mathrm{kg}$ body weight) exhibited significant $(P=0.01)$ reduction in tumor growth as compared with vehicle-treated mice without evidence of systemic toxicity (Fig. 7a). A representative mouse from each treatment group is shown in Fig. $7 \mathrm{~b}$; the treated mouse has reduced tumor mass compared with the control mouse.

\section{In vivo inhibition of angiogenesis and increase in necrosis with celecoxib treatment}

Vascularity of tumor implants was histologically evaluated using Masson's trichrome and factor VIII-related antigen staining. Tumors from celecoxib-treated mice showed reduced blood vessels as compared with tumors excised from vehicletreated mice (Fig. 8). Furthermore, there was evidence of necrosis in the celecoxib-treated tumors relative to those obtained from vehicle-treated animals (Fig. 8a,b).

\section{Discussion}

The results presented here clearly show that celecoxib strongly suppresses cell growth and proliferation in both human breast cancer cell lines (Fig. 1b). However, the mechanism of antitumor effect is dependent upon COX-2 expression and the invasive properties of the cancer cell. The highly invasive MDA-MB-231 cells undergo induction of apoptosis (Fig. 2) and the less invasive MDA-MB-468 cells undergo cell cycle arrest (Fig. 4) after treatment with celecoxib. The two cell lines exhibit different levels of COX-2 protein expression, with MDA-MB-231 cells expressing much higher levels than MDA-MB-468 cells (Fig. 1a), which directly correlated with the amount of $\mathrm{PGE}_{2}$ production by the cells (Table 1 ) and their invasive properties. Our data are in good agreement with the postulate that elevated production of COX-2-induced prostanoids is a hallmark of highly metastasizing breast cancer cells $[41,42]$. The two cell lines regulate COX-2 protein differently after celecoxib treatment, with downregulation of the protein observed in MDA-MB-468 cells but not in MDA-MB-231 cells (Fig. 1a). In fact there was an increase in COX-2 expression in MDA-MB-231 cells at the $60 \mu \mathrm{mol} / \mathrm{l}$ level of celecoxib, the mechanism for which is not known. However, one or more COX-produced products may repress COX expression in a negative feedback loop. Removal of negative feedback by celecoxib treatment would result in COX-2 induction. There are similar reports on celecoxib treatment leading to strong upregulation of COX-2 protein expression in 184htert breast cancer cells [43].

Regardless of COX-2 expression and regulation patterns, celecoxib treatment reduced $\mathrm{PGE}_{2}$ secretion by both cell lines (Table 1), but provision of exogenous $\mathrm{PGE}_{2}$ reversed celecoxib-induced growth inhibition in the MDA-MB-468 cells only, and not in the MDA-MB-231 cells (Fig. 5). This suggests that celecoxib-induced growth inhibition of the highly aggressive MDA-MB-231 cells is independent of $P G E_{2}$. Corroborating our findings are previous reports that growth inhibition induced by COX-2 inhibitors in some carcinoma cell lines can be completely abrogated by exogenous addition of $\mathrm{PGE}_{2}$ [44], whereas in other studies addition of $P G E_{2}$ had no effect $[45,46]$. One possible $\mathrm{PGE}_{2}$-independent mechanism by which celecoxib may have caused apoptosis in MDA-MB-231 
Figure 6

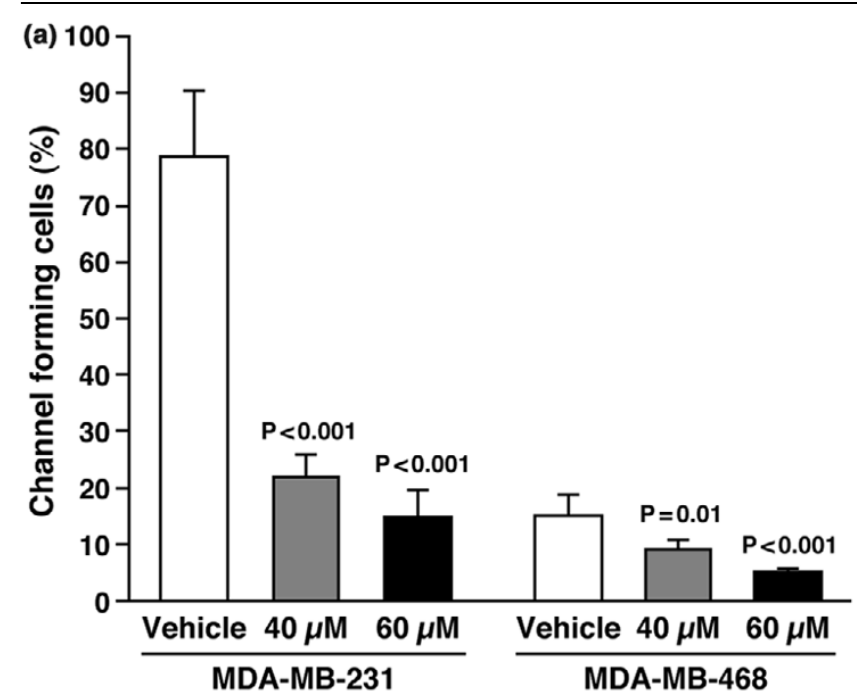

(b)

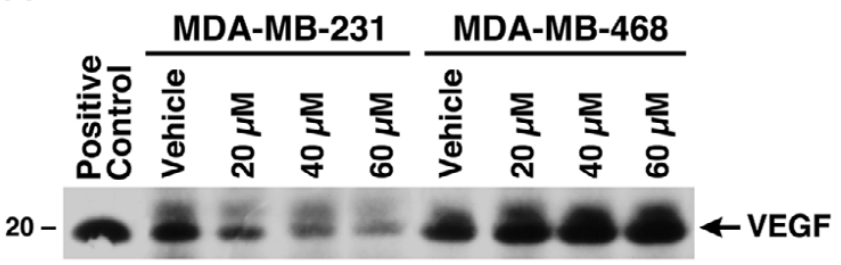

Celecoxib treatment causes reduction in microvascular channel formation by regulating VEGF levels. (a) The percentage of cells forming channels was much greater in MDA-MB-231 cells than in MDA-MB468 cells. In both cells, treatment with 40 and $60 \mu \mathrm{mol} / \mathrm{l}$ celecoxib caused significant reduction in the number of channels. $P$ values represent significant differences between vehicle control and celecoxib treatment. (b) Western blot analysis of cell lysates prepared from vehicle and celecoxib $(20-60 \mu \mathrm{mol} / \mathrm{l})$ treated cells. SDS-PAGE electrophoresis was performed using $15 \%$ resolving gel. Protein was loaded at 100 $\mu \mathrm{g}$ per lane and the protein was detected using vascular endothelial growth factor (VEGF) antibody. Celecoxib treatment decreased VEGF levels in MDA-MB-231 cells in a dose-dependent manner.

cell lines could be through the accumulation of the prostaglandin precursor arachidonic acid. Arachidonic acid is known to be converted to an intermediate, apoptosis-signaling compound, namely ceramide, which causes NSAID-induced apoptosis in cancer cells [47]. This phenomenon of ceramideinduced apoptosis has been proven in a murine mammary tumor cell line treated with celecoxib [18]. Because $P E_{2}$ is the major prostanoid released from breast cancer cells [41], we focused our studies on $\mathrm{PGE}_{2}$ levels. However, a possible role of other prostanoids such as $\mathrm{PGD}_{2}, \mathrm{PGI}, \mathrm{PGF}_{2 \alpha}$ and thromboxane ${ }_{2}$ cannot be ruled out, and future studies will include analyses of other prostanoids.

Thus, we observed that the mechanisms driving celecoxibinduced growth inhibition are very diverse in the two cells lines, depending upon COX-2 expression levels, invasive properties, and dependence on $\mathrm{PGE}_{2}$. At the cellular level, celecoxib induced the characteristic features of apoptosis in the MDA-MB-231 cells (Fig. 2). At the molecular level, activation of protein kinase B/Akt was significantly reduced at 60 $\mu \mathrm{mol} / \mathrm{l}$ concentration of celecoxib, with increased activation of proapoptotic protein Bax and caspases 3 and 7 (Fig. 3). These results are in agreement with those of other studies in which it was suggested that activation of effector caspases 3 and 7 and Bax proteins, downstream of phosphoinositide 3-kinase/ Akt inactivation, was the mechanism of celecoxib-induced tumor cell apoptosis [22,48]. Mechanisms leading to the downregulation of Akt activation are not clear. It has been suggested that inhibition of the tumor suppressor PTEN, a phosphatase that targets phosphoinositol triphosphate, or inhibition of 3-phosphoinositide-dependent kinase 1 activity may be involved [48-50].

In contrast to MDA-MB-231 cells, growth of MDA-MB-468 cells was inhibited by induction of cell cycle arrest at the $G_{0} /$ $\mathrm{G}_{1}$ phase of the cell cycle (Fig. 4). Similar cell cycle arrest has been reported using a murine mammary tumor cell line derived from a spontaneously occurring tumor [18], human pancreatic cancer cell lines [51], and human ovarian cancer cell lines [52]. It is not clear from our studies that celecoxib directly affects cell cycle distribution by regulating cyclin $D_{1}$ levels, which is one of the major cyclins known to be upregulated during cancer. Preliminary data evaluating cyclin $D_{1}$ levels in MDA-MB-468 cells after celecoxib treatment were inconclusive (data not shown) and more thorough analysis is needed. The question remains whether COX-2 induced $\mathrm{PGE}_{2}$ can directly regulate cyclin $D_{1}$ or other network of cyclins, cyclindependent kinases (CDKs) or CDK inhibitors. For other cell types, including colon, lung and squamous cell carcinomas, it has been reported that treatment with NSAIDs results in upregulation of CDK inhibitors that regulate accumulation of cells in $\mathrm{G}_{0} / \mathrm{G}_{1}$ [53-55]. In breast cancer cells, this remains to be examined.

Angiogenesis plays a crucial role in tumor development and progression. COX-2 dependent $\mathrm{PGE}_{2}$ production represents a likely candidate for the angiogenic response observed in several tumors, including mammary tumors [36,56-58]. To explore the role played by COX-2 inhibitors in angiogenesis, we used both in vitro and in vivo model systems. Aggressive breast epithelial cells are known to differentiate into tubules when cultured on growth factor reduced Matrigel. This phenomenon is known as vasculogenic mimicry. Its presence has been reported in inflammatory breast cancer patients and is associated with reduced 5-year survival and higher percentage of recurrence [59]. Shirakawa and coworkers [40] suggested a connection between vascular mimicry and angiogenesis, based on the existence of blood flow in the vascular channels. When plated on growth factor reduced Matrigel, human breast cancer cell lines have the unique ability to form tubular channels. We showed that the more aggressive MDA-MB-231 cells generate channels more efficiently and in higher numbers than do the less aggressive MDA-MB- 
Figure 7

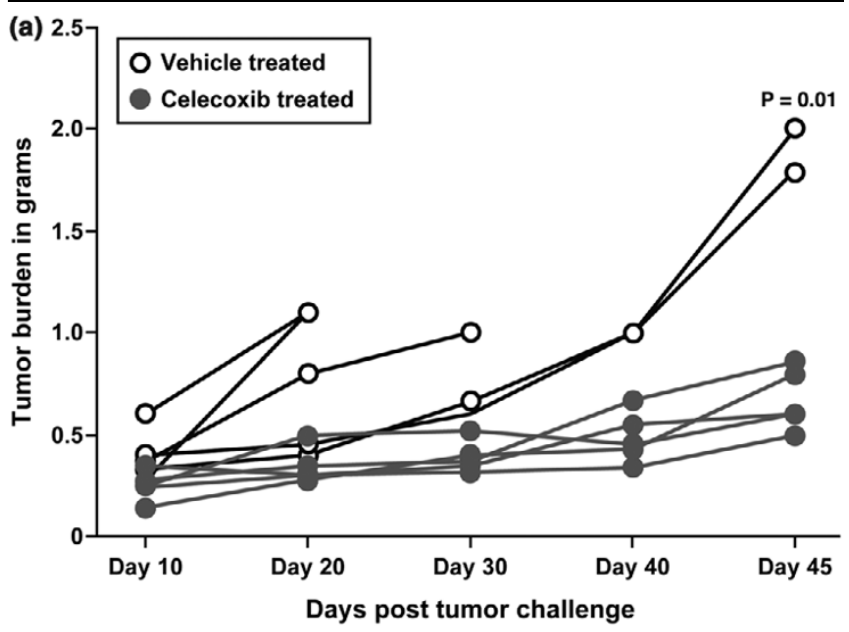

(b)
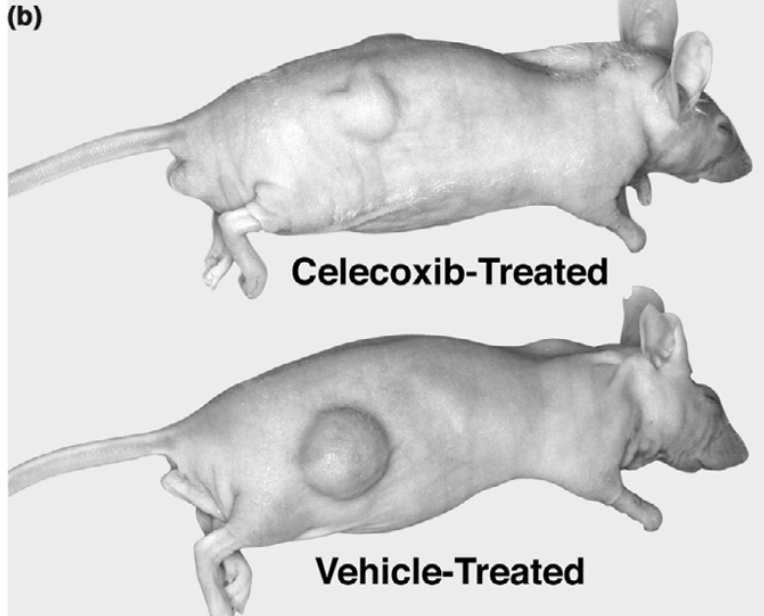

Celecoxib treatment reduced MDA-MB-231 tumor growth in nude mice. (a) Five mice per group were treated with either celecoxib (25 $\mathrm{mg} / \mathrm{kg}$ body weight) or vehicle (dimethyl sulfoxide) and the mice were killed 45 days after the tumor cells were inoculated. Tumor growth was monitored by weekly examination using digital calipers, and tumor weight was calculated using to the following equation [23]: tumor weight $(\mathrm{g})=\left(\right.$ length $(\mathrm{cm}) \times$ width $\left.(\mathrm{cm})^{2}\right) \times 0.5$. Three mice from the vehicle-treated group had to be killed early because of the aggressive nature of the tumor. The other two mice in the vehicle-treated group had significantly greater tumor burden $(P=0.01)$ than did the five mice in celecoxib-treated group. (b) A representative mouse from each treatment group is illustrated; lower tumor mass Is evident in the treated animal as compared with the vehicle control.

468 cell line (Fig. 6a). Similarly, it was shown that highly aggressive melanoma cells, when seeded on three-dimensional matrices of collagen I, form extracellular matrix-rich patterned networks that surround clusters of tumor cells; however, under the same culture conditions, poorly aggressive melanoma cells did not form the patterned networks [38]. When treated with increasing concentrations of celecoxib (40-60 $\mu \mathrm{mol} / \mathrm{l})$ we observed a dose-dependent decrease in the ability of both cell lines to differentiate into channels (Fig. $6 a)$. Our findings are in accordance with those of other

\section{Figure 8}
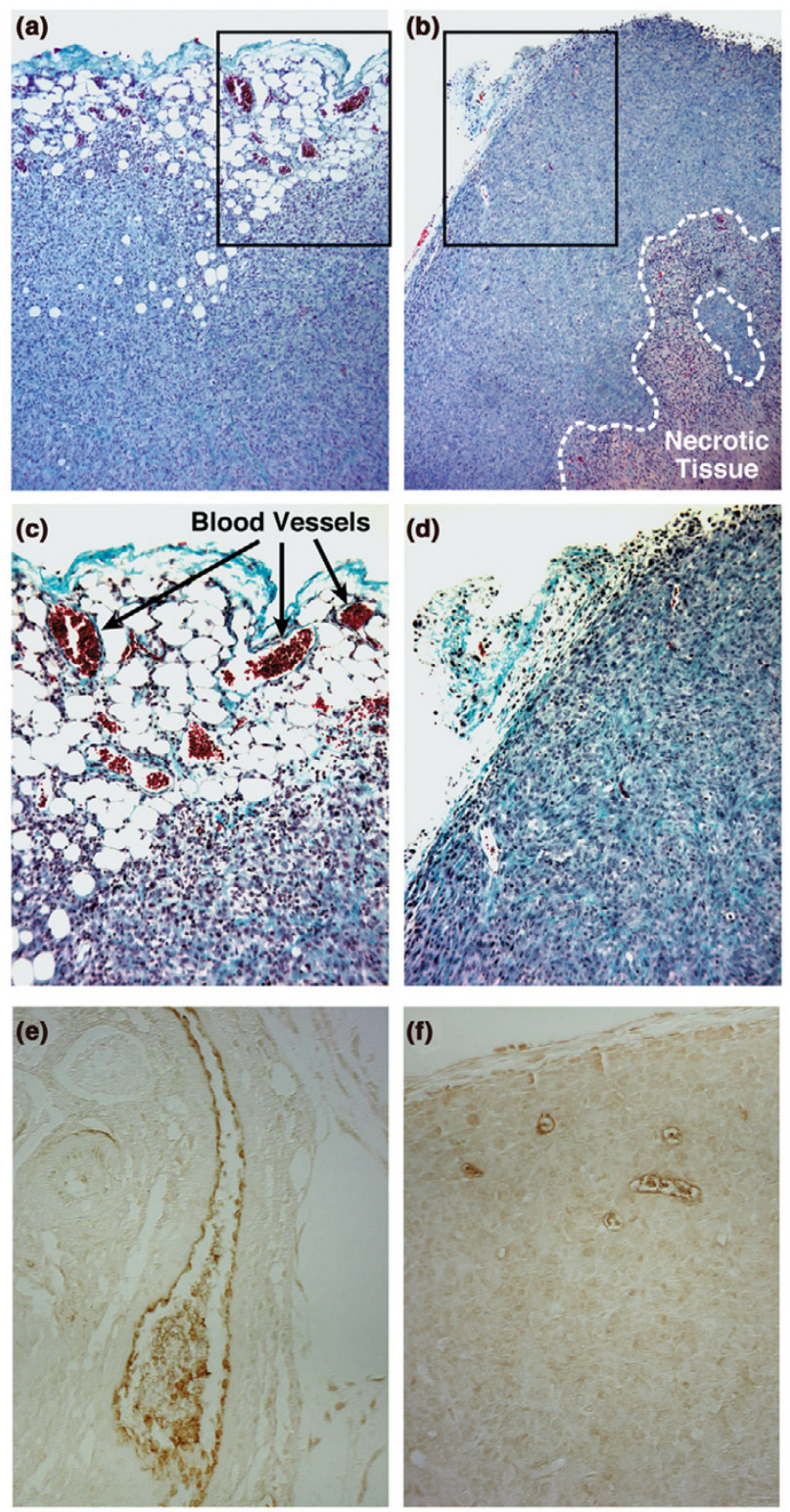

Vehicle-Treated

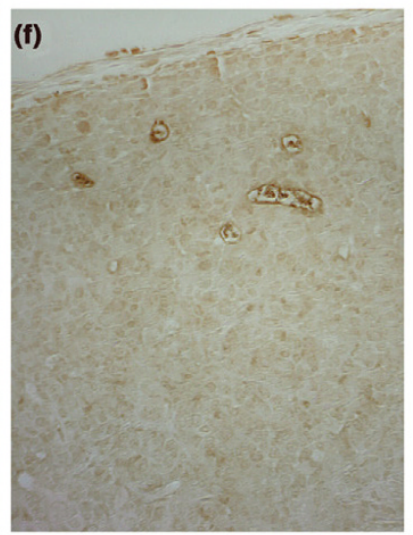

Celecoxib-Treated

In vivo inhibition of angiogenesis and increase in necrosis with celecoxib treatment. Vascularity of tumor implants was histologically evaluated by Masson's trichrome and factor VIII related antigen staining. Shown is evidence of central necrosis and decreased number of blood vessels in (b) a section of celecoxib-treated tumors relative to (a) a section obtained from a vehicle-treated animal (magnification 50x). Greater magnification (100x) of (c) panel a and (d) panel b are shown in the next two panels. Arrows in panel c point to blood vessels.

Endothelial cells lining the blood vessels stained positively for factor VIII related antigen and showed larger blood vessels in the (e) vehicletreated than in the $(\mathbf{f})$ celecoxib-treated samples (magnification 100x).

reports, in which capillary-like tube formation by human umbilical vein endothelial cells cocultured with COX-2 overexpress- 
ing Caco-2 cells was inhibited by a COX-2 selective inhibitor, NS-398, in a dose-dependent manner [60].

COX-2 inhibitors have already been reported to inhibit angiogenesis, and our study shows for the first time that COX-2 regulates vascular channel formation in human breast cancer cells. The mechanism of action of celecoxib in inhibiting channel formation is not known. Our data suggest that treatment with celecoxib caused a dose-dependent downregulation of VEGF in the MDA-MB-231 cells but not in the MDA-MB-468 cells (Fig. 6b). Although additional mechanisms are involved in mediating the angiogenic effects of COX-2, our data imply that COX-2 inhibitors influence angiogenesis at least in part by decreasing the release of VEGF. It was recently reported that COX-2 induced $\mathrm{PGE}_{2}$ stimulated the expression of angiogenic regulatory genes, including VEGF, in mammary tumor cells isolated from COX-2 transgenic mice, and that treatment with indomethacin (a nonspecific COX inhibitor) suppressed the expression of these genes in vitro [36]. To confirm the in vitro data, the antiangiogenic effects of celecoxib were evaluated in an in vivo xenograft model using MDA-MB-231 cell containing Matrigel implants. Results showed that celecoxib dramatically reduced the vascularity within the tumor tissue (Fig. 8). In addition, the treatment caused increased necrosis and reduced viable tissue mass within the tumor (Figs 7 and 8). Therefore, the reduced tumor burden in the treated mice can be explained in part by the inhibition of angiogenesis and confirms our in vitro data. Previous studies have reported similar effects of COX-2 inhibitors in an in vivo angiogenesis assay using the highly metastatic murine mammary tumor cell line C3L5 [45]. Additional studies are needed to fully elucidate the complex events involved in COX-2 mediated angiogenesis in human mammary tumors.

To our knowledge, this is the first study to identify some key mechanisms of action of celecoxib in vitro and in vivo in human breast cancer cells. More cell lines must be evaluated to characterize fully the antitumor actions of celecoxib, including identification of its primary targets, the precise molecular mechanism of cell damage, and the basis for its preferential effect on tumor cells. Although COX-2 inhibitor treatment alone is unlikely to eliminate an existing tumor, it is likely that it can confer significant benefit as part of a carefully chosen regimen involving other drugs. The strategy to target multiple pathways simultaneously may be critical to improving the efficacy of therapy in the treatment of breast cancer, especially for metastatic breast cancer. Moore and coworkers [61] reported that celecoxib, in combination with 5-fluorouracil or cyclophosphamide, greatly enhanced the antitumor effects of chemotherapy in a colon cancer model. In another tumor model, COX-2 selective inhibitors showed promise in combination with radiation therapy, enhancing tumor radiation responses [62]. Celecoxib was recently shown to have chemopreventive effects against the development of chemically induced mammary tumors in the rat [12]. Finally, recent evi- dence that combined treatment with a nonselective NSAID and EGFR tyrosine kinase inhibitor significantly decreased polyp formation in Min $\mathrm{APC}^{+/-}$mice supports the notion that combination therapy may be more effective [63]. These studies, combined with the present study and the reports of aberrant COX-2 expression in human breast cancer [9,64], suggest that selective COX-2 inhibitors have an important role to play in chemoprevention, chemo-intervention, and therapy of human breast cancer.

\section{Conclusion}

We showed that the mechanisms driving celecoxib-induced growth inhibition of human breast cancer cells are dependent upon COX-2 expression levels, invasive properties, and dependence on $\mathrm{PGE}_{2}$. At the cellular level, celecoxib induced apoptosis in highly invasive cells, but it caused cell cycle arrest at the $G_{0} / G_{1}$ phase of the cell cycle without causing apoptosis in the less invasive cells. At the molecular level, pAkt was inactivated with increased activation of proapoptotic protein Bax and caspases 3 and 7. Furthermore, we showed for the first time that celecoxib inhibited microvascular channel formation in a dose-dependent manner, associated with downregulation of VEGF in the highly invasive cells. An in vivo xenograft model confirmed the in vitro data and showed dramatic reduction in tumor mass accompanied by reduced vascularity and increased necrosis within the tumor, suggesting that the reduced tumor burden in the treated mice may in part be due to reduced angiogenesis.

\section{Competing interests}

The author(s) declare that they have no competing interests.

\section{Authors' contributions}

GDB conducted the mouse studies including daily gavaging, palpating tumors and monitoring tumor growth, as well as endpoint assays such as apoptosis, and caspase assays. LBP and TLT performed the western blotting and $P_{G} E_{2}$ assays. SJG provided expert scientific advice with regard to the MTag transgenic mice and mammary carcinogenesis. PM is the $\mathrm{Pl}$ of the laboratory in which all experiments were conducted and is the recipient of the grant that funded the project. She was instrumental in writing the manuscript.

\section{Acknowledgements}

This study was supported by a grant from the Susan G Komen Breast Cancer Foundation (BCTR0202089) to PM. We thank Dr Ronald J Marler for his help in evaluating the histologic specimens, Leslie Dixon for helping with histology, Jim Tarara for helping with the confocal studies and flow cytometry, Marvin H Ruona for help with the graphic production, Scott Dulla for helping with photography, and Carol Williams for preparation of the manuscript.

\section{References}

1. Harris RE, Chlebowski RT, Jackson RD, Frid DJ, Ascenseo JL, Anderson G, Loar A, Rodabough RJ, White E, McTiernan A: Breast cancer and nonsteroidal anti-inflammatory drugs: pro- 
spective results from the Women's Health Initiative. Cancer Res 2003, 63:6096-6101.

2. Lee PP, Ip MM: Regulation of proliferation of rat mammary tumor cells by inhibitors of cyclooxygenase and lipoxygenase. Prostaglandins Leukot Essent Fatty Acids 1992, 45:21-31.

3. Robertson FM, Parrett ML, Joarder FS, Ross M, Abou-lssa HM, Alshafie G, Harris RE: Ibuprofen-induced inhibition of cyclooxygenase isoform gene expression and regression of rat mammary carcinomas. Cancer Lett 1998, 122:165-175.

4. Alshafie GA, Harris RE, Robertson FM, Parrett ML, Ross M, AbouIssa $\mathrm{H}$ : Comparative chemopreventive activity of ibuprofen and $\mathrm{N}$-(4-hydroxyphenyl) retinamide against the development and growth of rat mammary adenocarcinomas. Anticancer Res 1999, 19:3031-3036.

5. Zhao Y, Agarwal VR, Mendelson CR, Simpson ER: Estrogen biosynthesis proximal to a breast tumor is stimulated by PGE2 via cyclic AMP, leading to activation of promoter II of the CYP19 (aromatase) gene. Endocrinology 1996, 137:5739-5742.

6. Brueggemeier RW, Quinn AL, Parrett ML, Joarder FS, Harris RE, Robertson FM: Correlation of aromatase and cyclooxygenase gene expression in human breast cancer specimens. Cancer Lett 1999, 140:27-35.

7. Richards JA, Brueggemeier RW: Prostaglandin E2 regulates aromatase activity and expression in human adipose stromal cells via two distinct receptor subtypes. J Clin Endocrinol Metab 2003, 88:2810-2816.

8. Bandyopadhyay GK, Imagawa W, Wallace D, Nandi S: Linoleate metabolites enhance the in vitro proliferative response of mouse mammary epithelial cells to epidermal growth factor. $J$ Biol Chem 1987, 262:2750-2756.

9. Pockaj B, Basu GD, Pathangey LB, Gray RJ, Hernandez JL, Gendler SJ, Mukherjee P: Reduced T cell and dendritic cell function is related to COX-2 over-expression and prostaglandin E2 secretion in patients with breast cancer. Ann Surg Oncol 2004, 11:328-339.

10. Ristimaki A, Sivula A, Lundin J, Lundin M, Salminen T, Haglund C, Joensuu $\mathrm{H}$, Isola J: Prognostic significance of elevated cyclooxygenase-2 expression in breast cancer. Cancer Res 2002, 62:632-635.

11. Harris RE, Namboodiri KK, Farrar WB: Nonsteroidal antiinflammatory drugs and breast cancer. Epidemiology 1996, 7:203-205.

12. Harris RE, Alshafie GA, Abou-lssa H, Seibert K: Chemoprevention of breast cancer in rats by celecoxib, a cyclooxygenase 2 inhibitor. Cancer Res 2000, 60:2101-2103.

13. Howe LR, Subbaramaiah K, Patel J, Masferrer JL, Deora A, Hudis C, Thaler HT, Muller WJ, Du B, Brown AM, et al.: Celecoxib, a selective cyclooxygenase 2 inhibitor, protects against human epidermal growth factor receptor 2 (HER-2)/neu-induced breast cancer. Cancer Res 2002, 62:5405-5407.

14. Basu GD, Pathangey LB, Tinder TL, LaGioia M, Gendler SJ, Mukherjee P: Cyclooxygenase-2 inhibitor induces apoptosis in breast cancer cells in an in vivo model of spontaneous metastatic breast cancer. Proc Natl Acad Sci USA 2002, 2:632-642.

15. Liu CH, Chang SH, Narko K, Trifan OC, Wu MT, Smith E, Haudenschild C, Lane TF, Hla T: Overexpression of cyclooxygenase-2 is sufficient to induce tumorigenesis in transgenic mice. $J$ Biol Chem 2001, 276:18563-18569.

16. Muller-Decker K, Neufang G, Berger I, Neumann M, Marks F, Furstenberger G: Transgenic cyclooxygenase-2 overexpression sensitizes mouse skin for carcinogenesis. Proc Natl Acad Sci USA 2002, 99:12483-12488.

17. Takahashi $Y$, Kawahara F, Noguchi M, Miwa K, Sato H, Seiki M, Inoue $\mathrm{H}$, Tanabe T, Yoshimoto T: Activation of matrix metalloproteinase-2 in human breast cancer cells overexpressing cyclooxygenase-1 or -2. FEBS Lett 1999, 460:145-148.

18. Kundu N, Smyth MJ, Samsel L, Fulton AM: Cyclooxygenase inhibitors block cell growth, increase ceramide and inhibit cell cycle. Breast Cancer Res Treat 2002, 76:57-64.

19. Munkarah AR, Genhai Z, Morris R, Baker VV, Deppe G, Diamond MP, Saed GM: Inhibition of paclitaxel-induced apoptosis by the specific COX-2 inhibitor, NS398, in epithelial ovarian cancer cells. Gynecol Oncol 2003, 88:429-433.

20. Williams CS, Watson AJ, Sheng H, Helou R, Shao J, DuBois RN: Celecoxib prevents tumor growth in vivo without toxicity to normal gut: lack of correlation between in vitro and in vivo models. Cancer Res 2000, 60:6045-6051.
21. Hsu AL, Ching TT, Wang DS, Song X, Rangnekar VM, Chen CS: The cyclooxygenase-2 inhibitor celecoxib induces apoptosis by blocking Akt activation in human prostate cancer cells independently of Bcl-2. J Biol Chem 2000, 275:11397-11403.

22. Lai GH, Zhang Z, Sirica AE: Celecoxib acts in a cyclooxygenase2-independent manner and in synergy with emodin to suppress rat cholangiocarcinoma growth in vitro through a mechanism involving enhanced Akt inactivation and increased activation of caspases-9 and -3. Mol Cancer Ther 2003, 2:265-271.

23. Jones MK, Wang H, Peskar BM, Levin E, Itani RM, Sarfeh IJ, Tarnawski AS: Inhibition of angiogenesis by nonsteroidal antiinflammatory drugs: insight into mechanisms and implications for cancer growth and ulcer healing. Nat Med 1999, 5:1418-1423.

24. Simpson-Herrerns L, Lloyd HH: Kinetic parameters and growth curves for experimental tumor systems. Cancer Chemother $\operatorname{Rep} 1970,54: 143-174$.

25. Jadeski LC, Lala PK: Nitric oxide synthase inhibition by N(G)nitro-L-arginine methyl ester inhibits tumor-induced angiogenesis in mammary tumors. $A m$ J Pathol 1999, 155:1381-1390.

26. Tsujii M, DuBois RN: Alterations in cellular adhesion and apoptosis in epithelial cells overexpressing prostaglandin endoperoxide synthase 2. Cell 1995, 83:493-501.

27. Liu XH, Yao S, Kirschenbaum A, Levine AC: NS398, a selective cyclooxygenase-2 inhibitor, induces apoptosis and down-regulates bcl-2 expression in LNCaP cells. Cancer Res 1998, 58:4245-4249.

28. Datta SR, Dudek H, Tao X, Masters S, Fu H, Gotoh Y, Greenberg ME: Akt phosphorylation of BAD couples survival signals to the cell-intrinsic death machinery. Cell 1997, 91:231-241.

29. del Peso L, Gonzalez-Garcia M, Page C, Herrera R, Nunez G: Interleukin-3-induced phosphorylation of BAD through the protein kinase Akt. Science 1997, 278:687-689.

30. Cardone MH, Roy N, Stennicke HR, Salvesen GS, Franke TF, Stanbridge E, Frisch S, Reed JC: Regulation of cell death protease caspase-9 by phosphorylation. Science 1998, 282:1318-1321.

31. Scheid MP, Woodgett JR: Unravelling the activation mechanisms of protein kinase B/Akt. FEBS Lett 2003, 546:108-112.

32. Susin SA, Zamzami N, Castedo M, Daugas E, Wang HG, Geley S, Fassy F, Reed JC, Kroemer G: The central executioner of apoptosis: multiple connections between protease activation and mitochondria in Fas/APO-1/CD95- and ceramide-induced apoptosis. J Exp Med 1997, 186:25-37.

33. Keane RW, Srinivasan A, Foster LM, Testa MP, Ord T, Nonner D, Wang HG, Reed JC, Bredesen DE, Kayalar C: Activation of CPP32 during apoptosis of neurons and astrocytes. $J$ Neurosci Res 1997, 48:168-180.

34. Krajewski S, Gascoyne RD, Zapata JM, Krajewska M, Kitada S Chhanabhai M, Horsman D, Berean K, Piro LD, Fugier-Vivier I, et al:: Immunolocalization of the ICE/Ced-3-family protease, CPP32 (Caspase-3), in non-Hodgkin's lymphomas, chronic lymphocytic leukemias, and reactive lymph nodes. Blood 1997, 89:3817-3825.

35. Hirpara JL, Seyed MA, Loh KW, Dong H, Kini RM, Pervaiz S: Induction of mitochondrial permeability transition and cytochrome $C$ release in the absence of caspase activation is insufficient for effective apoptosis in human leukemia cells. Blood 2000, 95:1773-1780.

36. Chang SH, Liu CH, Conway R, Han DK, Nithipatikom K, Trifan OC, Lane TF, Hla T: Role of prostaglandin E2-dependent angiogenic switch in cyclooxygenase 2 -induced breast cancer progression. Proc Natl Acad Sci USA 2004, 101:591-596.

37. Shirakawa K, Tsuda H, Heike Y, Kato K, Asada R, Inomata M, Sasaki $H$, Kasumi $F$, Yoshimoto $M$, Iwanaga $T$, et al:: Absence of endothelial cells, central necrosis, and fibrosis are associated with aggressive inflammatory breast cancer. Cancer Res 2001, 61:445-451.

38. Maniotis AJ, Folberg R, Hess A, Seftor EA, Gardner LM, Pe'er J, Trent JM, Meltzer PS, Hendrix MJ: Vascular channel formation by human melanoma cells in vivo and in vitro: vasculogenic mimicry. Am J Pathol 1999, 155:739-752.

39. Folberg R, Hendrix MJ, Maniotis AJ: Vasculogenic mimicry and tumor angiogenesis. Am J Pathol 2000, 156:361-381. 
40. Shirakawa K, Kobayashi H, Heike Y, Kawamoto S, Brechbiel MW, Kasumi F, Iwanaga T, Konishi F, Terada M, Wakasugi H: Hemodynamics in vasculogenic mimicry and angiogenesis of inflammatory breast cancer xenograft. Cancer Res 2002, 62:560-566.

41. Timoshenko AV, Xu G, Chakrabarti S, Lala PK, Chakraborty C: Role of prostaglandin E2 receptors in migration of murine and human breast cancer cells. Exp Cell Res 2003, 289:265-274.

42. Liu $X H$, Rose DP: Differential expression and regulation of cyclooxygenase -1 and -2 in two human breast cancer cell lines. Cancer Res 1996, 56:5125-5127.

43. Levitt RJ, Buckley J, Blouin MJ, Schaub B, Triche TJ, Pollak M: Growth inhibition of breast epithelial cells by celecoxib is associated with upregulation of insulin-like growth factor binding protein-3 expression. Biochem Biophys Res Commun 2004, 316:421-428.

44. Minter HA, Eveson JW, Huntley S, Elder DJ, Hague A: The cyclooxygenase 2-selective inhibitor NS398 inhibits proliferation of oral carcinoma cell lines by mechanisms dependent and independent of reduced prostaglandin E2 synthesis. Clin Cancer Res 2003, 9:1885-1897.

45. Rozic JG, Chakraborty C, Lala PK: Cyclooxygenase inhibitors retard murine mammary tumor progression by reducing tumor cell migration, invasiveness and angiogenesis. Int J Cancer 2001, 93:497-506.

46. Elder DJ, Halton DE, Crew TE, Paraskeva C: Apoptosis induction and cyclooxygenase-2 regulation in human colorectal adenoma and carcinoma cell lines by the cyclooxygenase-2selective non-steroidal anti-inflammatory drug NS-398. Int $J$ Cancer 2000, 86:553-560.

47. Chan TA, Morin PJ, Vogelstein B, Kinzler KW: Mechanisms underlying nonsteroidal antiinflammatory drug-mediated apoptosis. Proc Natl Acad Sci USA 1998, 95:681-686.

48. Soengas MS, Lowe SW: Apoptosis and melanoma chemoresistance. Oncogene 2003, 22:3138-3151.

49. Maehama T, Taylor GS, Dixon JE: PTEN and myotubularin: novel phosphoinositide phosphatases. Annu Rev Biochem 2001, 70:247-279.

50. Arico S, Pattingre S, Bauvy C, Gane P, Barbat A, Codogno P, Ogier-Denis E: Celecoxib induces apoptosis by inhibiting 3phosphoinositide-dependent protein kinase-1 activity in the human colon cancer HT-29 cell line. J Biol Chem 2002, 277:27613-27621.

51. Yip-Schneider MT, Sweeney CJ, Jung SH, Crowell PL, Marshall MS: Cell cycle effects of nonsteroidal anti-inflammatory drugs and enhanced growth inhibition in combination with gemcitabine in pancreatic carcinoma cells. J Pharmacol Exp Ther 2001, 298:976-985.

52. Denkert C, Furstenberg A, Daniel PT, Koch I, Kobel M, Weichert W, Siegert A, Hauptmann S: Induction of G0/G1 cell cycle arrest in ovarian carcinoma cells by the anti-inflammatory drug NS-398, but not by COX-2-specific RNA interference. Oncogene 2003, 22:8653-8661

53. Goldberg Y, Nassif II, Pittas A, Tsai LL, Dynlacht BD, Rigas B, Shiff SJ: The anti-proliferative effect of sulindac and sulindac sulfide on HT-29 colon cancer cells: alterations in tumor suppressor and cell cycle-regulatory proteins. Oncogene 1996, 12:893-901.

54. Toyoshima T, Kamijo R, Takizawa K, Sumitani K, Ito D, Nagumo M: Inhibitor of cyclooxygenase-2 induces cell-cycle arrest in the epithelial cancer cell line via up-regulation of cyclin dependent kinase inhibitor p21. Br J Cancer 2002, 86:1150-1156.

55. Hung WC, Chang HC, Pan MR, Lee TH, Chuang LY: Induction of p27(KIP1) as a mechanism underlying NS398-induced growth inhibition in human lung cancer cells. Mol Pharmacol 2000, 58:1398-1403.

56. Ben-Av P, Crofford LJ, Wilder RL, Hla T: Induction of vascular endothelial growth factor expression in synovial fibroblasts by prostaglandin $E$ and interleukin-1: a potential mechanism for inflammatory angiogenesis. FEBS Lett 1995, 372:83-87.

57. Seno H, Oshima M, Ishikawa TO, Oshima H, Takaku K, Chiba T, Narumiya S, Taketo MM: Cyclooxygenase 2- and prostaglandin $E(2)$ receptor EP(2)-dependent angiogenesis in Apc(Delta716) mouse intestinal polyps. Cancer Res 2002, 62:506-511.

58. Chu J, Lloyd FL, Trifan OC, Knapp B, Rizzo MT: Potential involvement of the cyclooxygenase-2 pathway in the regulation of tumor-associated angiogenesis and growth in pancreatic cancer. Mol Cancer Ther 2003, 2:1-7.

59. Shirakawa K, Wakasugi H, Heike Y, Watanabe I, Yamada S, Saito $\mathrm{K}$, Konishi $\mathrm{F}$ : Vasculogenic mimicry and pseudo-comedo formation in breast cancer. Int J Cancer 2002, 99:821-828.

60. Tsujii M, Kawano S, Tsuji S, Sawaoka H, Hori M, DuBois RN Cyclooxygenase regulates angiogenesis induced by colon cancer cells. Cell 1998, 93:705-716.

61. Moore RJ, Zweifel BS, Heuvelman DM, Leahy KM, Edwards DA Woerner BM, Ornberg RL, Seibert K, Koki AT, Masferrer JL: Enhanced antitumor activity co-administration of celecoxib and the chemotherapeutic agents cyclophosphamide and 5fu. Proceedings of the American Association for Cancer Research: 1-5 April 2000. Cadmus Journal Services, Linthicum, MD. USA. Abstract $2600: 409$

62. Kishi K, Petersen S, Petersen C, Hunter N, Mason K, Masferrer JL, Tofilon PJ, Milas L: Preferential enhancement of tumor radioresponse by a cyclooxygenase-2 inhibitor. Cancer Res 2000, 60:1326-1331.

63. Torrance CJ, Jackson PE, Montgomery E, Kinzler KW, Vogelstein B, Wissner A, Nunes M, Frost P, Discafani CM: Combinatorial chemoprevention of intestinal neoplasia. Nat Med 2000 6:1024-1028.

64. Soslow RA, Dannenberg AJ, Rush D, Woerner BM, Khan KN, Masferrer J, Koki AT: COX-2 is expressed in human pulmonary, colonic, and mammary tumors. Cancer 2000, 89:2637-2645. 